\title{
A Preliminary Modified Volumetric Mix Design for Self-Compacting Concrete (SCC) by Utilizing Asphalt Dust Waste (ADW)
}

\author{
Isham Ismail ${ }^{1}$, and Shahiron Shahidan ${ }^{1, *}$ \\ ${ }^{1}$ Jamilus Research Centre, Faculty of Civil and Environmental Engineering, Universiti Tun Hussein \\ Onn Malaysia, 86400 Batu Pahat, Johor, Malaysia
}

\begin{abstract}
The construction of asphalt roads has been commonly used as for infrastructure development since ancient times. The production of asphalt using drum mix plants has created powder waste in the premix batching plant industry. It consists of very fine powders and causesproblems to the environment today. However, powder waste can be successfully and economically utilized in the development of selfcompacting concrete (SCC). The aim of this study is to evaluate the fresh properties and the compressive strength of SCC containing asphalt dust waste (ADW). For this purpose, a simple modified volumetric mix design approach based on the Okumura Method was adapted to produce SCC mixes. In order to obtain this SCC, a series of SCC mixes with a specific water/binder ratio $(0.3)$, superplasticizer ratio $(2 \%)$ as well as different amounts of aggregate, sand and ADW were prepared. Fresh properties of the SCC mix were tested using tests such as slump-flow, J-Ring, L-box and $\mathrm{V}$-funnel which showed satisfactory results for $\mathrm{MD} 8_{40}$ and $\mathrm{MD} 8_{50}$. The compressive strength for $\mathrm{MD}_{40}$ and $\mathrm{MD} 8_{50}$ after 28 days was $40.8 \mathrm{MPa}$ and $34.7 \mathrm{MPa}$ respectively. In conclusion, the simple modified volumetric mix design method by utilizing ADW in SCC can be suggested for the development of SCC.
\end{abstract}

\section{Introduction}

Concrete is a common material that has been used for housing, tunnel, foundation, precast elements, high rise buildings and many other types of construction all over the world [1]. In 1986, Self Compacting Concrete (SCC) was introduced by Okamura as a solution for producing durable self-leveling concrete, which can flow and be compacted by its own weight into every corner of the formwork during placing and without requiring the vibrating process for normal vibrated concrete [2].

Through this development, it has become a great opportunity for researchers and the concrete industry to produce more economical and durable SCC by utilizing waste material either for granular or powder replacement in the development of SCC [3-7]. The performance of waste material incorporated in SCC varies and it depends on the physical

* Corresponding author: shahiron@uthm.edu.my 
and chemical properties of the materials used [4, 8, 9]. However, there are no specific methods that can be claimed as a standard to produce SCC. It depends on actual situations to obtain high quality SCC with satisfactory properties such as filling ability, passing ability and stability [10-11].

In short, this paper presents a preliminary study based on a modified volumetric mix design method by utilizing ADW to improve the rheological properties in SCC. The results show good performance for fresh state SCC without segregation and bleeding effects. A compressive strength of more than $30 \mathrm{MPa}$ in the hardened state for $\mathrm{MD}_{40}$ and MD8 ${ }_{50}$ was also achieved.

\section{Modified volumetric mix design for SCC}

Generally, there are many methods to produce SCC and it is not restricted to any standard at this moment [12-14]. Researchers from academic institutions, concrete batching plants, precast plants and developers have developed their own mix proportioning methods [13].

In this experimental research, a total of 6 types SCC mixtures were produced. It was a modified method based on recommendations from Okamura's method as well as a EFNARC specifications. This simplified mix design method is based on a volumetric ratio to allocate amounts of cement, aggregate, sand and ADW by percentage from total volume required. Each mix was prepared by fixing $25 \%$ of cement content from the total volume, varying amounts of granular (aggregate and sand) and ADW, a water/binder ratio of 0.3 and $2 \%$ super plasticiser. The details of the volumetric mix design flow and mix proportion in volumetric ratio are shown in Fig. 1 and Table 1.

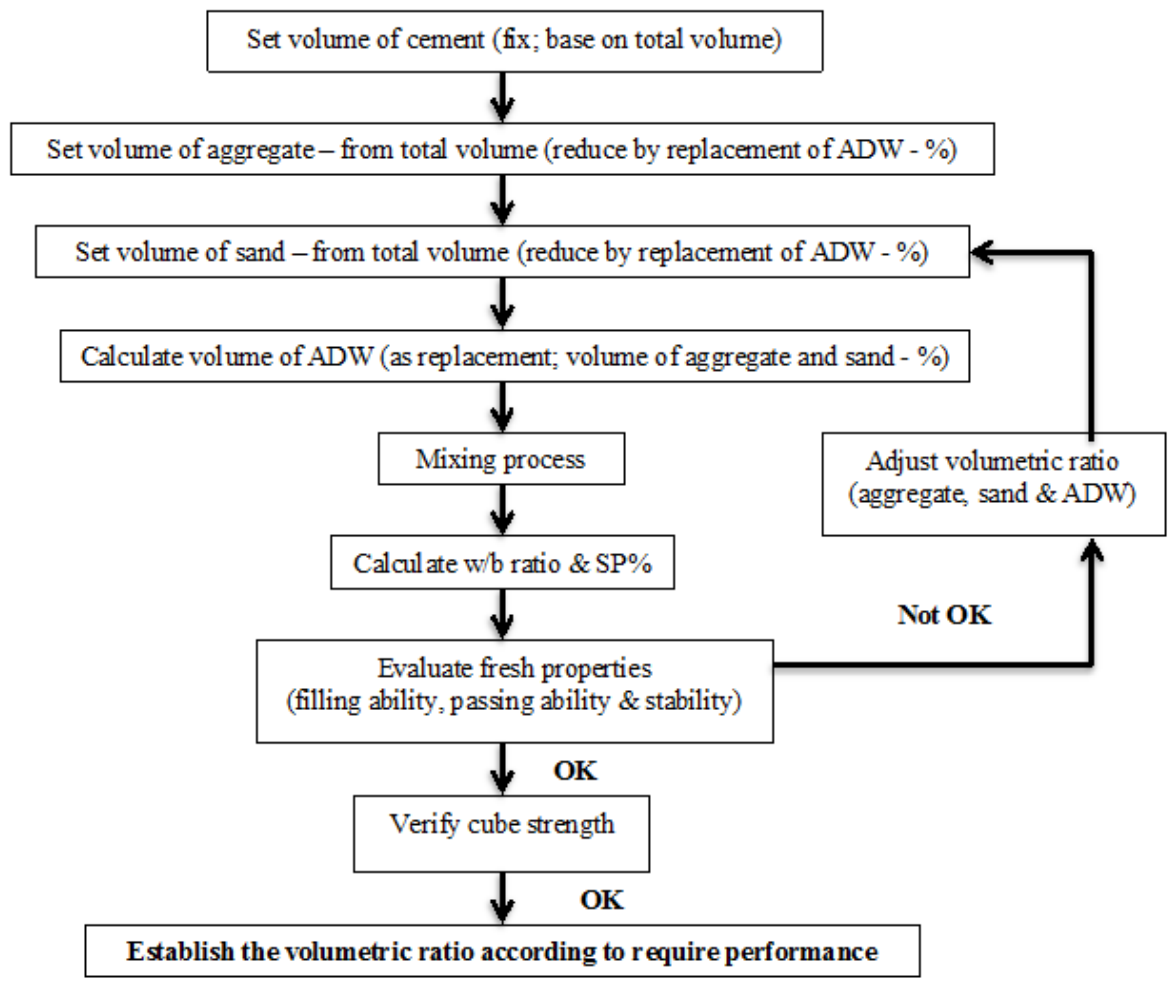

Fig. 1. Modified volumetric mix design procedure. 
After several trials, this simplified mix design method obtained satisfactory fresh test criteria. Finally, the detailed actual mix design ratio was calculated as preliminary data for the production of SCC by utilizing ADW as shown in Table 3 and 4.

Table 1. Mix proportion in volumetric ratio.

\begin{tabular}{|c|c|c|c|c|c|c|}
\hline \multirow{2}{*}{$\begin{array}{l}\text { Mix } \\
\text { types }\end{array}$} & \multicolumn{4}{|c|}{ Main Materials } & \multirow[b]{2}{*}{$\mathbf{w} / \mathbf{b}$} & \multirow{2}{*}{ SP } \\
\hline & Cement & Aggregate & Sand & ADW & & \\
\hline MD8 $_{0}$ & \multirow{6}{*}{ 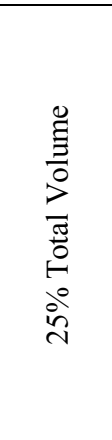 } & $60 \% \mathrm{TV}$ & $15 \% \mathrm{TV}$ & $\begin{array}{l}0 \% \text { x (vol. agg. + } \\
\text { vol. sand) }\end{array}$ & \multirow{6}{*}{0.3} & \multirow{6}{*}{$2 \%$} \\
\hline MD8 $_{10}$ & & $\begin{array}{l}(60 \% \mathrm{TV})-(10 \% x \\
60 \% \mathrm{TV})\end{array}$ & $\begin{array}{l}(15 \% \text { TV })-(10 \% x \\
15 \% \text { TV })\end{array}$ & $\begin{array}{l}10 \% \times \text { (vol. agg. }+ \\
\text { vol. sand) }\end{array}$ & & \\
\hline $\mathrm{MD8}_{20}$ & & $\begin{array}{l}(60 \% \text { TV })-(20 \% x \\
60 \% \text { TV })\end{array}$ & $\begin{array}{l}(15 \% \mathrm{TV})-(20 \% \mathrm{x} \\
15 \% \mathrm{TV})\end{array}$ & $\begin{array}{l}20 \% \mathrm{x} \text { (vol. agg. }+ \\
\text { vol. sand) }\end{array}$ & & \\
\hline MD8 $_{30}$ & & $\begin{array}{l}(60 \% \mathrm{TV})-(30 \% x \\
60 \% \mathrm{TV})\end{array}$ & $\begin{array}{l}(15 \% \text { TV })-(30 \% x \\
15 \% \mathrm{TV})\end{array}$ & $\begin{array}{l}30 \% \mathrm{x} \text { (vol. agg. + } \\
\text { vol. sand) }\end{array}$ & & \\
\hline $\mathrm{MD8}_{40}$ & & $\begin{array}{l}(60 \% \mathrm{TV})-(40 \% x \\
60 \% \mathrm{TV})\end{array}$ & $\begin{array}{l}(15 \% \mathrm{TV})-(40 \% \mathrm{x} \\
15 \% \mathrm{TV})\end{array}$ & $\begin{array}{l}40 \% \times \text { x (vol. agg. }+ \\
\text { vol. sand) }\end{array}$ & & \\
\hline MD8 $_{50}$ & & $\begin{array}{l}(60 \% \mathrm{TV})-(50 \% x \\
60 \% \mathrm{TV})\end{array}$ & $\begin{array}{l}(15 \% \mathrm{TV})-(50 \% \mathrm{x} \\
15 \% \mathrm{TV})\end{array}$ & $\begin{array}{l}50 \% \times \text { (vol. agg. + } \\
\text { vol. sand) }\end{array}$ & & \\
\hline
\end{tabular}

\section{Experimental studies}

There are many types of mix design methods and alternative materials for the development of SCC [10-11]. The main principles of developed SCC are to achieve the fresh properties, which are filling ability, passing ability and stability without compromising the strength of the hardened SCC. Therefore, this research mainly focuses on developing a simple volumetric mix design method by utilizing ADW for SCC.

$\mathrm{ADW}$ is a powder waste generated from the production of asphalt premix for road construction pavements using drum mix plants. Based on previous studies, it is a potential material to improve the rheological properties of fresh SCC such as Fly Ash, Silica Fume, Granulated Blast Furnace Slag, Ground Glass Filler, Ceramic Powder Waste and Marble Powder Waste [4 ],[7-8],[15]. SEM photographs for ADW are shown in Fig. 2. ADW has angular shapes with a rough surface texture. Hence, this is an opportunity to use waste material in the development of sustainable concrete products in order to create a better environment for the local community.
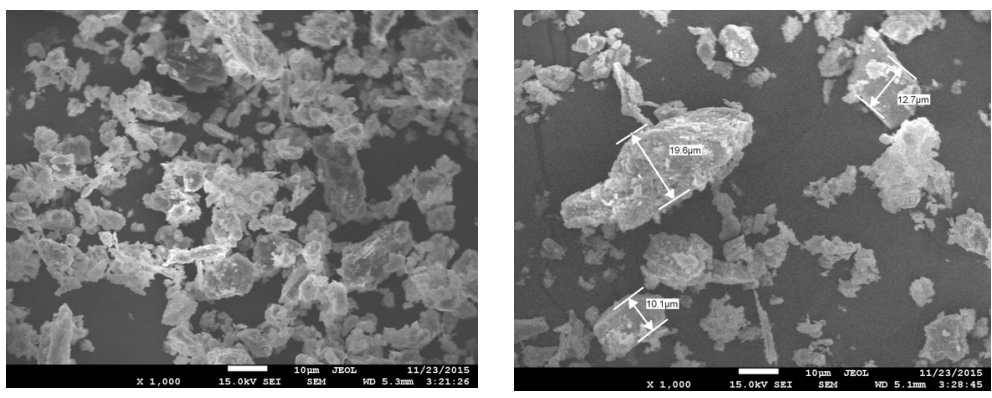

Fig. 2. Angular shape and rough surface texture of ADW from SEM analysis.

However, the performance of ADW in terms of rheological properties is still questionable. Therefore, this preliminary research has used ADW as an alternative powder waste material to produce paste materials and at the same time explore a new approach to 
develop SCC in a lab by using a modified volumetric mix design ratio. The mixtures were established and evaluated through observation and tests on the fresh properties (slump flow, J Ring, L Box and V Funnel). The performance of hardened concrete strength was measured through a cube test after 7 and 28 days respectively.

\subsection{Materials}

The production of SCC in this research was done using modified volumetric mix design ratio. The amount of cement, aggregate, sand and ADW will be calculated as mentioned in Table 1 with a suitable water binder ratio $(0.3)$ and superplasticizer content $(2 \%)$. The chemical properties of cement, sand, aggregate and ADW are shown in Table 2.

Table 2. The chemical properties of cement, sand, aggregate and ADW.

\begin{tabular}{|c|c|c|c|c|}
\hline Properties & Cement OPC & Chipping & Sand & ADW \\
\hline Calcium Oxide, $(\mathrm{CaO})$ & $55.60 \%$ & $1.85 \%$ & - & $2.98 \%$ \\
\hline Silicon Dioxide, $(\mathrm{SiO} 2)$ & $14.20 \%$ & $43.70 \%$ & $30.10 \%$ & $44.00 \%$ \\
\hline Aluminum Oxide, $(\mathrm{Al} 2 \mathrm{O} 3)$ & $3.68 \%$ & $8.50 \%$ & $2.13 \%$ & $9.22 \%$ \\
\hline Iron $(\mathrm{III})$ Oxide, $(\mathrm{Fe} 2 \mathrm{O} 3)$ & $3.49 \%$ & $3.38 \%$ & $0.30 \%$ & $4.24 \%$ \\
\hline Sulfur Trioxide, $(\mathrm{SO} 3)$ & $3.20 \%$ & - & - & - \\
\hline Magnesium Oxide, $(\mathrm{MgO})$ & $1.48 \%$ & $0.49 \%$ & & $0.62 \%$ \\
\hline Carbon, $(\mathrm{C})$ & $1.00 \%$ & $1.00 \%$ & $1.00 \%$ & $1.00 \%$ \\
\hline Potassium Oxide, $(\mathrm{K} 2 \mathrm{O})$ & $0.48 \%$ & & $0.19 \%$ & $4.69 \%$ \\
\hline Zirconium Dioxide, $(\mathrm{ZrO} 2)$ & - & - & $0.47 \%$ & - \\
\hline Titanium Dioxide, $(\mathrm{TiO} 2)$ & - & $0.39 \%$ & $0.32 \%$ & $0.46 \%$ \\
\hline Sodium Oxide, $(\mathrm{Na} 2 \mathrm{O})$ & - & - & - & $1.00 \%$ \\
\hline Titanium, $(\mathrm{Ti})$ & $0<\mathrm{LLD}$ & - & - & - \\
\hline Calcium, $(\mathrm{Ca})$ & - & - & $0<\mathrm{LLD}$ & - \\
\hline Phosphorus, $(\mathrm{P})$ & - & $0<\mathrm{LLD}$ & - & $0<\mathrm{LLD}$ \\
\hline (S) & - & - & - & $0<\mathrm{LLD}$ \\
\hline Zirconium, $(\mathrm{Zr})$ & - & - & - & $0<$ LLD \\
\hline
\end{tabular}

Local Ordinary Portland Cement according to MS EN 197-1, CEM I $42.5 \mathrm{~N}$ was used in all mixes. The maximum aggregate size and sand grain size was $12 \mathrm{~mm}$ and $4 \mathrm{~mm}$ respectively. The gradation curves of the granular materials are shown in Fig. 3. The aggregates, sand and ADW were air dried prior to mixing. 2\% of superplasticizer Darex Super 20 was used in order to increase the workability of SCC for all mixes. Meanwhile, the water binder ratio used was set to 0.3 .

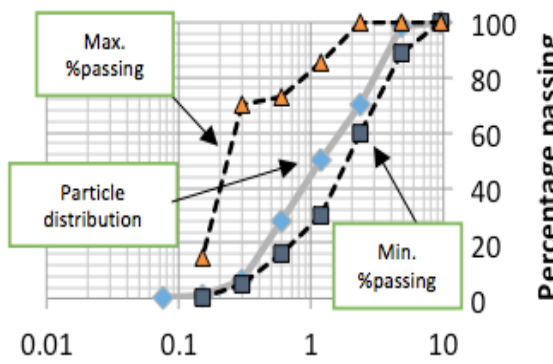

Sieve size $(\mathrm{mm})$

(a)

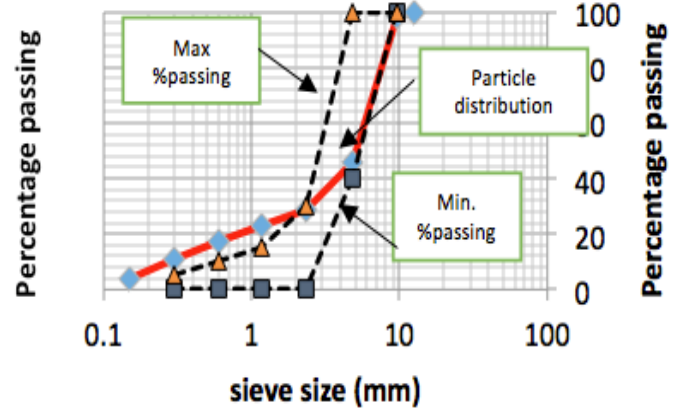

(b)

Fig. 3. Particle distribution of the granular materials (a) sand (b) aggregate. 


\subsection{Test equipment}

Self-compacting concrete is also known as self-consolidating concrete. It is a highly workable concrete that can flow inside the formwork system and spread through reinforcement under its own weight during the fresh state $[2,11]$. Therefore, these fresh properties should be tested and evaluated for filling ability (V-Funnel test), passing ability (L-Box) and stability (slump flow and J Ring test). Filling ability is the capability of the concrete to flow and fill all spaces or shapes created in the formwork system without using vibration tools. Passing ability is the ability of concrete to flow through and bond to reinforcement bars without any blocking under its own weight. Stability is the performance of internal resistance from the concrete mixture to flow without segregation [16].

\subsection{Calculation of modified volumetric mix design method}

The aim of developing a procedure using modified volumetric mix design method is to produce a simple understanding on the distribution of cement, aggregate, sand and ADW using locally available materials. This design procedure may require interpolation distribution of materials to achieve target compressive strength after a series of trial mixes [12].

Calculation of Modified Volumetric Ratio (MVR) is based on Volumetric Ratio (VR) and controlled by Weight Ratio (WR) as shown in Table 3 and 4. Conversion of VR to WR is based on the estimation of packing factor in 1 liter of each material. The estimated packing factor for cement is 1.15, 1.33 for aggregates, 1.6 for sand and 1.05 for ADW.

Table 3. Volumetric ratio (VR) for 1000 litre mixture.

\begin{tabular}{|c|c|c|c|c|c|c|c|c|c|c|c|c|}
\hline \multirow{2}{*}{$\begin{array}{l}\text { 1000 } L \\
\text { volume }\end{array}$} & \multicolumn{2}{|c|}{ MD8 $_{0}$} & \multicolumn{2}{|c|}{ MD8 $_{10}$} & \multicolumn{2}{|c|}{ MD8 $_{20}$} & \multicolumn{2}{|c|}{ MD8 $_{30}$} & \multicolumn{2}{|c|}{ MD8 $_{40}$} & \multicolumn{2}{|c|}{ MD8 $_{50}$} \\
\hline & VR & $\%$ & VR & $\%$ & VR & $\%$ & VR & $\%$ & VR & $\%$ & VR & $\%$ \\
\hline Cement & 250 & 25 & 250 & 25 & 250 & 25 & 250 & 25 & 250 & 25 & 250 & 25 \\
\hline Agg. & 600 & 60 & 540 & 54 & 480 & 48 & 420 & 42 & 360 & 36 & 300 & 30 \\
\hline Sand & 15 & 15 & 135 & 13.5 & 120 & 12 & 105 & 10. & 90 & 9 & 75 & 7.5 \\
\hline ADW & 0 & 0 & 75 & 7.5 & 150 & 15 & 225 & 22.5 & 300 & 30 & 375 & 37.5 \\
\hline
\end{tabular}

Table 4. Weight ratio (WR) for 1000 litre mixture base on volumetric ratio (VR).

\begin{tabular}{|c|c|c|c|c|c|c|c|c|c|c|c|c|}
\hline \multirow{2}{*}{$\begin{array}{l}1000 L \\
\text { volume }\end{array}$} & \multicolumn{2}{|l|}{ MD8 $_{0}$} & \multicolumn{2}{|c|}{ MD8 $_{10}$} & \multicolumn{2}{|c|}{ MD8 $_{20}$} & \multicolumn{2}{|c|}{ MD8 $_{30}$} & \multicolumn{2}{|c|}{ MD8 $_{40}$} & \multicolumn{2}{|c|}{ MD8 $_{50}$} \\
\hline & WR & $\%$ & WR & $\%$ & WR & $\%$ & WR & $\%$ & WR & $\%$ & WR & $\%$ \\
\hline & & & & 22 & & 22 & & 23.0 & & + & & \\
\hline & & & & 5 & & & & 44. & & 1 & & 3.3 \\
\hline & & & & 16 & & 15 & & 10 & & 11.7 & & 10.0 \\
\hline ADI & 0 & 0 & 78.9 & 6.1 & 158 & 12.4 & 236.9 & 19.0 & 15.9 & 25.7 & 394.9 & 32.8 \\
\hline
\end{tabular}

\section{Experimental results}

The fresh properties and compressive strength of developed ADW-SCC were measured as shown in Table 5 and illustrated in Fig. 4 and Fig. 5. Each mixture has a good workability as shown by slump flow values of more than $390 \mathrm{~mm}$. However, only MD8 40 and MD8 50 exceeded the minimum slump flow requirement of $500 \mathrm{~mm}$ and showed excellent performance during the fresh state in terms of stability, filling ability and passing ability and also compressive strength.

The compressive strength of the developed ADW-SCC against the various amounts of granular materials achieved the minimum target strength $(30 \mathrm{MPa})$ except for $\mathrm{MD} 8_{0}$. All of 
these performances were influenced by a significant amount of paste volume (cement and ADW) present in each mixture as shown in Fig. 6.

Table 5. Fresh properties of ADW-SCC.

\begin{tabular}{|c|c|c|c|c|c|}
\hline & \multicolumn{4}{|c|}{ Fresh State } & \multirow{2}{*}{$\begin{array}{l}\text { Compressive } \\
\text { strength } \\
\text { (MPa) }\end{array}$} \\
\hline & Slump Flow & J Ring (mm) & L box & $V$ funnel & \\
\hline MD8 $_{0}$ & 390 & - & - & - & 25.7 \\
\hline MD8 $_{10}$ & 445 & - & - & - & 34.7 \\
\hline MD8 $_{20}$ & 405 & - & - & - & 38.3 \\
\hline MD8 $_{30}$ & 440 & - & - & - & 46 \\
\hline $\mathbf{M D 8}_{40}$ & $\begin{array}{l}812 \mathrm{~mm}, \\
\mathrm{~T}_{500}=2 \mathrm{~s}\end{array}$ & $\begin{array}{l}760 \mathrm{~mm} \\
\mathrm{~T}_{500}=2 \mathrm{~s}, \\
\mathrm{H} 1=15 \mathrm{~mm} \\
\mathrm{H} 2=9 \mathrm{~mm} \\
\mathrm{H} 1 / \mathrm{H} 2=1.67\end{array}$ & $\begin{array}{l}\mathrm{T}_{20}=1 \mathrm{~s}, \\
\mathrm{~T}_{40}=2 \mathrm{~s}, \\
\mathrm{H} 1=90 \mathrm{~mm} \\
\mathrm{H} 2=88 \mathrm{~mm} \\
\mathrm{H} 1 / \mathrm{H} 2=1.0\end{array}$ & $\begin{array}{l}\mathrm{T}_{10 \mathrm{~s}}=12 \mathrm{~s} \\
\mathrm{~T}_{5 \mathrm{~m}}=15 \mathrm{~s}\end{array}$ & 40.8 \\
\hline MD8 $_{50}$ & $\begin{array}{l}830 \mathrm{~mm} \\
\mathrm{~T}_{500}=3 \mathrm{~s}\end{array}$ & $\begin{array}{l}785 \mathrm{~mm}, \\
\mathrm{~T}_{500}=3 \mathrm{~s}, \\
\mathrm{H} 1=20 \mathrm{~mm} \\
\mathrm{H} 2=20 \mathrm{~mm}, \\
\mathrm{H} 1 / \mathrm{H} 2=1.0\end{array}$ & $\begin{array}{l}\mathrm{T}_{20}=2 \mathrm{~s}, \\
\mathrm{~T}_{40}=3 \mathrm{~s}, \\
\mathrm{H} 1=90 \mathrm{~mm} \\
\mathrm{H} 2=90 \mathrm{~mm} \\
\mathrm{H} 1 / \mathrm{H} 2=1.0\end{array}$ & $\begin{array}{l}\mathrm{T}_{10 \mathrm{~s}}=11 \mathrm{~s} \\
\mathrm{~T}_{5 \mathrm{~m}}=18 \mathrm{~s}\end{array}$ & 34.7 \\
\hline
\end{tabular}

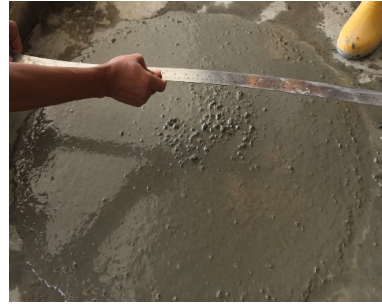

(a)

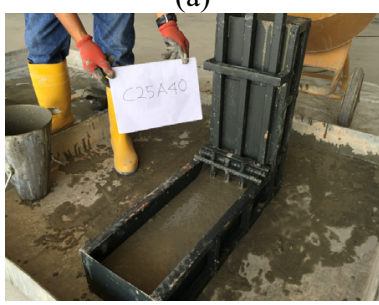

(c)

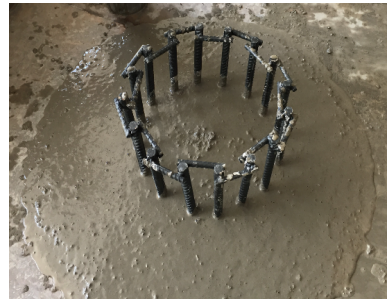

(b)

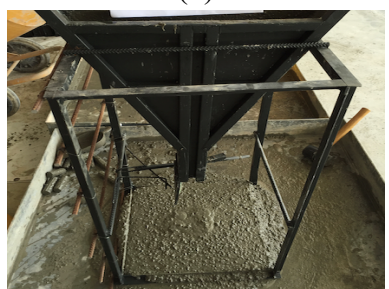

(d)

Fig. 4. Fresh state test using (a) slump flow test, (b) J Ring test, (c) L Box test and (d) V Funnel test.

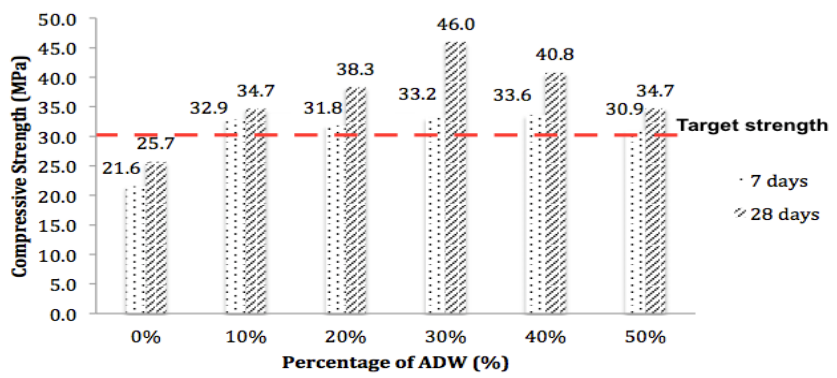

Fig. 5. Compressive strength measured on day 7 and day 28. 


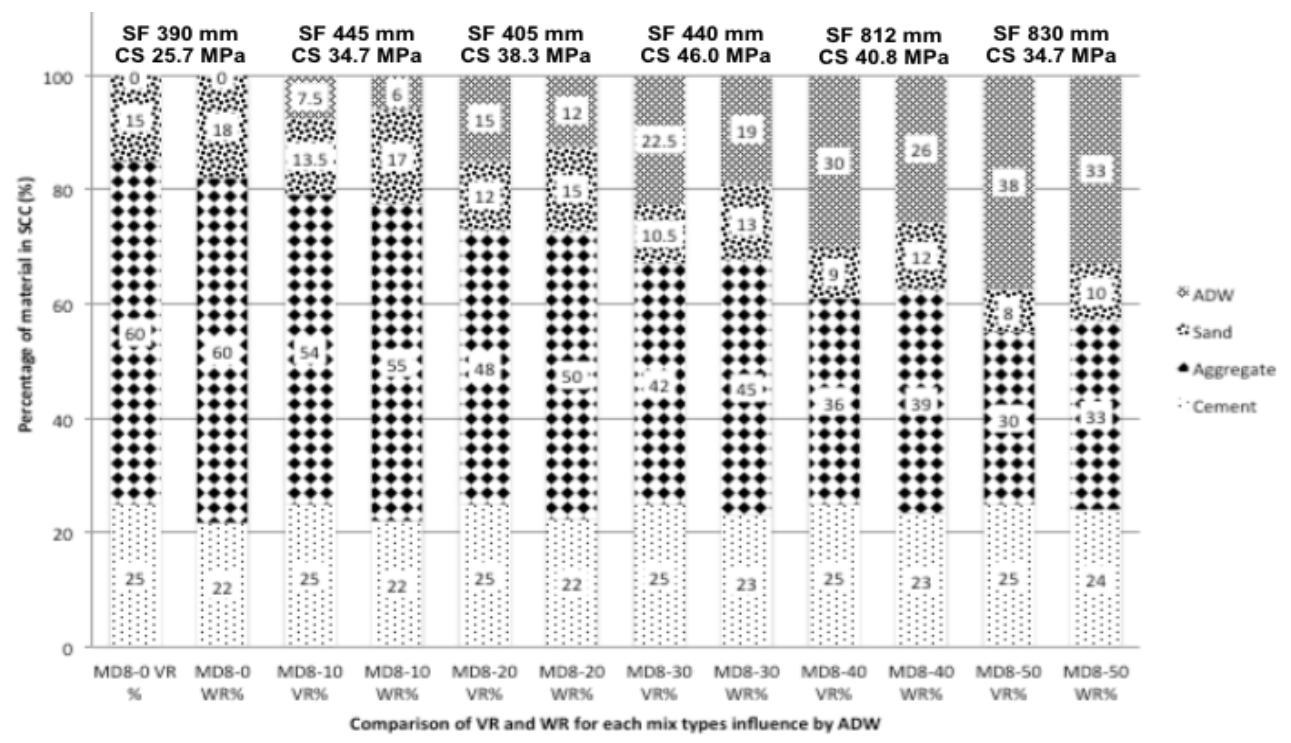

Fig. 6. Distribution of materials in ADW-SCC base on VR (\%) and WR (\%).

\section{Conclusions}

From the findings of this experimental modified volumetric mix design for self-compacting concrete by utilizing ADW, the following conclusions can be drawn:

i) The disposal of ADW materials from the premix batching industry is one of the major problems for the environment today. However, this study opens a new field for utilizing $\mathrm{ADW}$ in SCC and successfully proven and economically utilized ADW as a paste mixture to improve rheological properties in SCC technology. Furthermore, the physical properties of ADW showed that it is also suitable to be used as additional filler material to improve hardened strength in terms of packing factor.

ii) The distribution of materials is highly useful to produce ADW-SCC with reference to design slump flow (SF), compressive strength (CS) and material distribution. Moreover, $\mathrm{w} / \mathrm{b}$ ratio and amount of SP can be adjusted to achieve minimum slump flow. Higher $\mathrm{w} / \mathrm{b}$ ratio and SP (\%) will improve the rheological effect. However, lower w/b ratio and SP content is good for fracture toughness.

iii) Further studies on mortar paste volume should be carried out in order to evaluate the hardened performance of ADW-SCC. The amount of paste materials and $\mathrm{w} / \mathrm{b}$ ratio should be minimized to obtain high performance SCC.

In general, the development of modified volumetric mix design for SCC by utilizing ADW showed the possibility of producing high performance ADW-SCC. It can be concluded that ADW contributes to better stability, filling ability and passing ability of the ADW-SCC. However, further work needs to be done on the effect of ADW in terms of other aspects such as shrinkage, crack pattern, creep and other durability performances.

The authors gratefully acknowledge the Ministry of Higher Education Malaysia (MOHE) for providing financial support for authors and to Universiti Tun Hussein Onn Malaysia (UTHM) for providing the resources needed to complete this paper. 


\section{References}

[1] P.L. Domone, Self-compacting concrete: An analysis of 11 years of case studies, Cem. Concr. Compos., 28(2), 197-208, (2006)

[2] H. Okamura and M. Ouchi, Self-compacting concrete, Adv. Concr. Technol., 1(1), 5$15,(2003)$

[3] Y. Sheen, L.-J. Huang, T.H. Sun and D.H. Le, Engineering properties of selfcompacting concrete containing stainless steel slags, Procedia Eng., 142, 79-86, (2016)

[4] M. Benaicha, X. Roguiez, O. Jalbaud, Y. Burtschell and A. H. Alaoui, Influence of silica fume and viscosity modifying agent on the mechanical and rheological behavior of self compacting concrete, Constr. Build. Mater., 84, 103-110, (2015)

[5] D. Carro López, B. González Fonteboa, J. de Brito, F. Martínez-Abella, I. GonzálezTaboada and P. Silva, Study of the rheology of self-compacting concrete with fine recycled concrete aggregates, Constr. Build. Mater., 96, 491-501, (2015)

[6] E. Güneyisi, M. Gesoglu, A. Al-Goody and S. İpek, Fresh and rheological behavior of nano-silica and fly ash blended self-compacting concrete, Constr. Build. Mater., 95, 29-44, (2015)

[7] I. Ismail, N. Jamaluddin and S. Shahidan, A review on performance of waste materials in self compacting concrete (SCC), J. Teknol., 5, 29-35, (2016)

[8] K. E. Alyamaç and R. Ince, A preliminary concrete mix design for SCC with marble powders, Constr. Build. Mater., 23(3), 1201-1210, (2009)

[9] H. Y. Aruntas, Workability and mechanical properties of self-compacting concretes containing LLFA, GBFS and MC, 73, 626-635, (2014)

[10]C. Shi, Z. Wu, K. Lv and L. Wu, A review on mixture design methods for selfcompacting concrete, Constr. Build. Mater., 84, 387-398, (2015)

[11]EFNARC, Specification and guidelines for self-compacting concrete, United Kingdom, (2002)

[12]N. Su, K.C. Hsu and H.W. Chai, A simple mix design method for self-compacting concrete, Cem. Concr. Res., 31(12), 1799-1807, (2001)

[13]C. Selvamony, M. S. Ravikumar, S. U. Kannan and S. B. Gnanappa, Investigations on self-compacted self-curing concrete using limestone powder and clinkers, ARPN J. Eng. Appl. Sci., 5(3), 1-6, (2010)

[14] M. C. S. Nepomuceno, L. a. Pereira-De-Oliveira, S. M. R. Lopes and R. M. C. Franco, Maximum coarse aggregate's volume fraction in self-compacting concrete for different flow restrictions, Constr. Build. Mater., 113, 851-856, (2016)

[15]H. Zhao, W. Sun, X. Wu and B. Gao, The properties of the self-compacting concrete with fly ash and ground granulated blast furnace slag mineral admixtures, J. Clean. Prod., 95, 66-74, (2015)

[16]M.L. Ghambhir, Concrete technology (theory and practice), Fourth Eds, Tata McGrawhill Education Private Limited, (2009) 